Ekonomia - Wroclaw Economic Review 24/2 (2018)

Acta Universitatis Wratislaviensis

No 3858

DOI: 10.19195/2084-4093.24.2.7

Aldona Małgorzata Dereń

ORCID: 0000-0002-2377-4573

Politechnika Wrocławska

Wydział Informatyki i Zarządzania

aldona.deren@pwr.edu.pl

Jan Skonieczny

ORCID: 0000-0002-1027-991X

Politechnika Wrocławska

Wydział Informatyki i Zarządzania

jan.skonieczny@pwr.edu.pl

\title{
Organizacyjno-prawne problemy zabezpieczania zasobów intelektualnych w przedsiębiorstwie
}

Artykuł nadesłany: 15 listopada 2017 r.; artykuł zaakceptowany: 20 kwietnia 2018 r.

JEL Classification: K110, L590, M130

Keywords: intellectual property, strategic resource, knowledge, information

\section{Abstract}

Organizational and legal problems of securing intellectual resources in the enterprise

The goal of the research paper is to present intellectual property as an intangible resource in enterprise. The specific features of this resource and the base of competing (co-operation and rivalry) characteristic for a contemporary market make these core resources for development of not only a large company. In these circumstances it is a premise to create adjusted orientation on the search and exposure of immaterial values (but also their monitoring of competitors). Simultaneously this orientation is aimed at the choice of proper manners of protection of these values both within the organization, in the process of sharing both knowledge and information with other organizations on the market. 


\section{Wstęp}

Z dyskusji na temat finansowania MŚP w Polsce wynika potrzeba badania własności intelektualnej jako specyficznego zasobu zawierającego wiedzę i informację. Duże organizacje wypracowały już racjonalne sposoby na gospodarowanie i ochronę tych zasobów. Natomiast małe i średnie przedsiębiorstwa nadal na poziomie niedostatecznym gospodarują wiedzą i informacjami, które mają przecież realną wartość ekonomiczną. Nawet organizacje wypracowujące już pewne zasady, instrumenty lub modele biznesu nastawione na pozyskiwanie, gromadzenie czy dystrybuowanie wiedzy i informacji nie korzystają w pełni z systemu ochrony tych zasobów, przez co nie mogą zapewnić sobie korzyści ze swojej kreatywności.

Omawiane zasoby nierozerwalnie wiążą się z problemem ochrony instytucjonalnej i nieinstytucjonalnej zarówno w procesie tworzenia, jak i dzielenia się $\mathrm{z}$ innymi posiadaną wiedzą i informacjami. Taką ideę przyjął w swoich działaniach Elon Musk — właściciel firmy Tesla, działającej w branży motoryzacyjnej, który obecnie zajmuje się opracowaniem i wprowadzeniem na rynek samochodu elektrycznego. W 2014 roku udostępnił on bezpłatnie ponad 500 patentów stanowiących własność jego przedsiębiorstwa. Decyzję tę uzasadnił następująco:

Odczuwaliśmy potrzebę patentowania naszych rozwiązań z obawy przed tym, że duże koncerny motoryzacyjne skopiują naszą technologię i wykorzystają swoje rozbudowane infrastruktury produkcyjne, sprzedażowe i marketingowe w celu wyeliminowania nas z rynku. Nie mogliśmy bardziej się mylić. Smutna rzeczywistość wygląda zupełnie inaczej: programy rozwoju samochodów elektrycznych (i innych pojazdów niewykorzystujących węglowodorów) w dużych firmach motoryzacyjnych są bardzo skromne lub w ogóle nie istnieją — średnio rzecz biorąc, przekładają się znacznie mniej niż jeden procent całkowitej sprzedaży samochodów. (Krupp, Schoemaker 2016, s. 36)

Ta innowacyjna strategia podważa tradycyjny sposób myślenia przyjęty nie tylko w branży samochodowej, ponieważ opiera się na założeniu, że skuteczne konkurowanie wymaga współpracy, a nie rywalizacji. Musk określa tę strategię mianem „filozofii otwartości wiedzy” (Krupp, Schoemaker 2016, s. 37).

Przykład ten dowodzi, że współczesne przedsiębiorstwa coraz częściej muszą zwracać uwagę na konieczność ochrony własności intelektualnej wytworzonej przez ich pracowników oraz nowej wiedzy i informacji, które zgromadziły w toku prowadzonej działalności gospodarczej. Konieczność ta wynika z faktu, że zasoby niematerialne, w tym wynalazki i nowe technologie, od wielu lat nabierają kluczowego znaczenia w rozwoju przedsiębiorstw oraz w procesie budowania przez nie przewagi konkurencyjnej. Uznaje się, że w gospodarce opartej na wiedzy źródłem sukcesu nie są same alokacje rzadkich zasobów — osiąganie sukcesu związane jest z tworzeniem nowej wiedzy, która bierze się z pomysłów i nowych idei, a te jako dobra niematerialne są istotnym składnikiem kreowania wartości materialnej organizacji. O randze dóbr niematerialnych świadczy nadanie im miana „czwartego czynnika produkcji” oraz podstawy władzy organizacyjnej (Sikorski 2001, s. 274). Zasoby te są ściśle powiązane z jednostką w tym znaczeniu, że 
są ,generowane" przez człowieka i rozwijają się w ludzkich umysłach, a ich specyficzne cechy wyznaczają im w procesie zarządzania przedsiębiorstwem status czynnika mającego znaczący wpływ na wartość i pozycję rynkową organizacji.

Celem niniejszego artykułu jest ukazanie własności intelektualnej jako zasobu niematerialnego pozostającego w dyspozycji przedsiębiorstwa. Specyficzne cechy tego zasobu oraz charakterystyczne dla współczesnego rynku zasady konkurowania (współpraca i rywalizacja) czynią je kluczowymi dla rozwoju nie tylko dużych przedsiębiorstw. Jest to również przesłanka do budowy orientacji nastawionej na poszukiwanie i eksponowanie niematerialnych wartości (a także monitorowanie ich u konkurentów). Równocześnie ma to ścisły związek z wyborem właściwych sposobów ochrony tych wartości zarówno wewnątrz organizacji, jak i w procesie dzielenia się wiedzą i informacją z innymi podmiotami rynkowymi.

\section{Własność intelektualna jako zasób niematerialny przedsiębiorstwa}

W praktyce społeczno-gospodarczej instytucja własności prawnej zajęła i utrzymuje niezwykle ważne miejsce oraz odgrywa kluczową rolę w procesie efektywnego rozwoju całej gospodarki (Stankiewicz 2012, s. 65). Powszechność tego pojęcia nabiera jednak nowego znaczenia, gdy potrzebne jest opisywanie własności intelektualnej.

Własność intelektualna to ogół wytworów ludzkiego umysłu, rezultatów twórczej pracy, talentu, wyobraźni, kreatywności i inwencji oraz określonych nakładów (czasu, kapitału finansowego i rzeczowego, aktualnego stanu techniki). Gdy powstają w organizacji, są wykorzystywane jako zasoby niematerialne w wytwarzaniu kolejnych dóbr i usług. Jak słusznie podkreślają Roger D. Blair i Thomas F. Cotter (2005, s. 1-2), własność intelektualną wyróżnia to, że można określić jej wartość ekonomiczną oraz że podlega ona ochronie prawnej. Należy zwrócić uwagę, że kiedy zasoby wiedzy stają się przedmiotem praw własności intelektualnej, możliwe jest czerpanie korzyści finansowych z tytułu rozpowszechniania i wykorzystywania tych zasobów: sprzedaży, transferu, komercjalizacji. $\mathrm{W}$ tym wypadku mamy również do czynienia $\mathrm{z}$ ochroną prawną przed ich nieuprawnionym używaniem dla celów komercyjnych (Bainbridge 2009, s. 22-30; Barrett 2008, s. 1-4; May 2007, s. 4-8).

Kathleen Allen (2010, s. 66) wyróżnia trzy grupy zasobów niematerialnych przedsiębiorstwa: kapitał intelektualny, aktywa intelektualne i własność intelektualną. Wzajemną zależność między nimi przedstawiono na rysunku 1. 


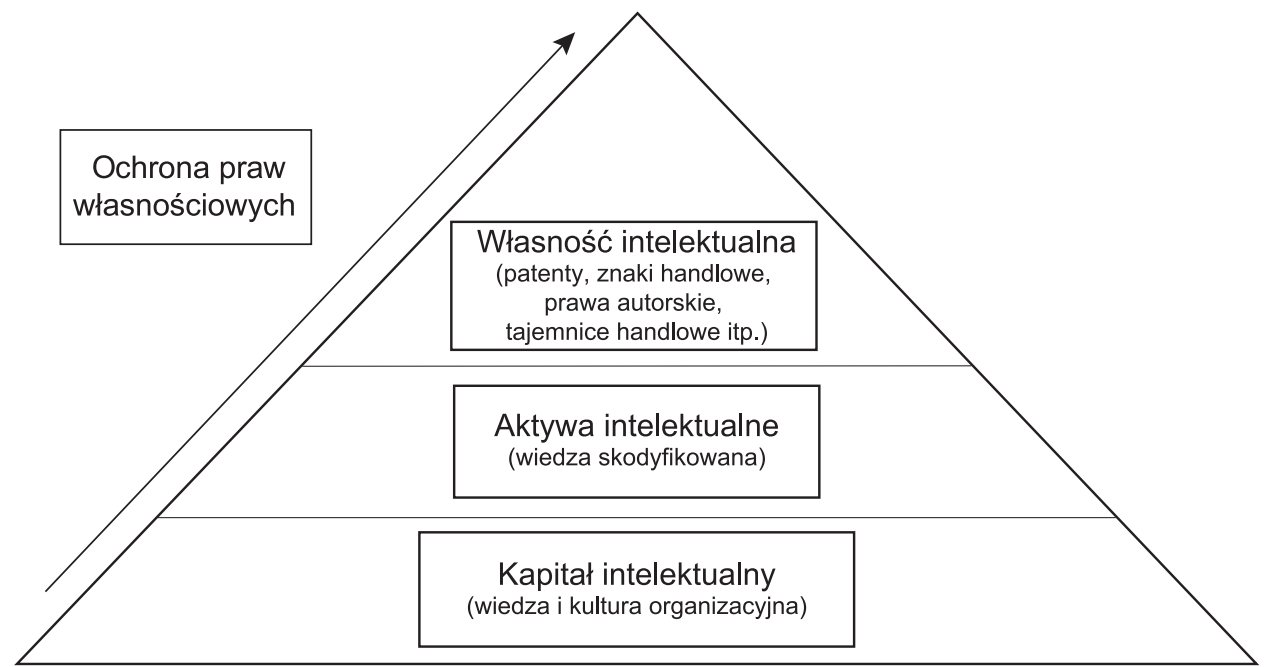

Rysunek 1. Piramida zasobów niematerialnych

Źródło: opracowanie własne na podstawie Allen 2010, s. 66.

W literaturze przedmiotu można znaleźć wiele definicji kapitału intelektualnego. Przegląd tych definicji został szeroko przedstawiony w pracy Stanisława Kasiewicza, Waldemara Rogowskiego i Moniki Kicińskiej. Jedna z tych definicji określa kapitał intelektualny jako „materiał intelektualny: wiedzę, informację, własność intelektualną i doświadczenie, które mogą być wykorzystane do tworzenia bogactwa (T. Steward)" (Kasiewicz et al. 2006, s. 70-71). Z kolei według innej definicji kapitał intelektualny to ,wiedza, która może być zamieniona na wartość (I. Edvinsson)" (Kasiewicz et al. 2006, s. 70-71). Kapitał intelektualny określany jest również jako „materia intelektualna, która została zmaterializowana, uchwycona i wykorzystana do stworzenia wysoko wartościowych aktywów (L. Prusak)" (Kasiewicz et al. 2006, s. 71).

Aktywa intelektualne nie są tak szeroko definiowane w literaturze przedmiotu jak kapitał intelektualny. Najczęściej są one traktowane jako aktywa wiedzy skodyfikowanej. Natomiast zamiennie używa się pojęcia „aktywa intelektualne” na określenie niemajątkowych aktywów, które organizacja posiada na własność w postaci kodowanej (na przykład dokumentacja, bazy danych), mogących być dla niej w przyszłości źródłem korzyści (wartości). Podobnie w rachunkowości aktywa określa się jako kontrolowane przez jednostkę (przedsiębiorstwo) zasoby majątkowe o wiarygodnie określonej wartości, powstałe w wyniku przeszłych zdarzeń, które spowodują w przyszłości wpływ korzyści ekonomicznych (Ujwary-Gil 2010, s. 89). Tak rozumiane aktywa, w tym aktywa wiedzy skodyfikowanej, mogą być kontrolowane przez przedsiębiorstwo, w przeciwieństwie do kapitału ludzkiego (wiedzy pracowników), który nie jest jego własnością. 
Rozszerzone ujęcie aktywów intelektualnych proponuje Andrew J. Sherman (2012, s. 74), który aktywa intelektualne określa jako pewną całość złożoną z:

- aktywów kulturowych, na które składają się: przywództwo i władza; organizacyjne normy i zwyczaje; zaufanie i prawość; misja, wizja i wartości; komunikacja i definiowanie celów; cel, odpowiedzialność; transparentność; system nagród i wynagrodzeń; systemy podejmowania decyzji;

— aktywów partnerskich rozumianych jako: reputacja korporacyjna i zewnętrzny/wewnętrzny wizerunek marki; status, propozycja wartości i jej wpływ na tworzenie partnerskich relacji z interesariuszami; budowanie lojalności wobec marki; kształtowanie relacji inwestycyjno-bankowych; tworzenie przedsiębiorstw typu joint venture i aliansów strategicznych; opracowywanie strategii sprzedaży, marketingu i marki; wdrażanie systemów zarządzania klientami; tworzenie sieci współpracy i rozwijanie dobrych praktyk;

— aktywów ludzkich, których rozwój opiera się na: ustawicznym kształceniu pracowników; tworzeniu ścieżek kariery zawodowej i awansów; doskonaleniu umiejętności zawodowych pracowników; rozwijaniu pracy zespołowej; zbieraniu doświadczeń; budowaniu lojalności wobec organizacji i przyjętych w niej wartości; wspieraniu i rozwijaniu twórczych i innowacyjnych postaw i zachowań; umożliwianiu dostępu do zasobów istniejących w organizacji;

- aktywów praktycznych i rutynowych, na które składają się: know-how i show-how (skodyfikowane w formalne i nieformalne procedury oraz ukryte zasady odnośnie do ich opracowywania); systemy i procesy zorientowane na ochronę informacji stanowiących know-how; transmisja i przepływ informacji oraz danych; pozyskiwanie i zarządzanie wiedzą chronioną; tworzenie kanałów przepływu i wymiany wiedzy wewnątrz organizacji i jej otoczeniu; doskonalenie umiejętności praktycznych i adoptowanie się do zmian w zarządzaniu oraz zmian na rynku.

Według Shermana (2012, s. 72-73) tak zdefiniowanymi aktywami intelektualnymi należy zarządzać; proces zarządzania jest tymczasem rodzajem strategii i zbierania informacji konkurencyjnych sprzyjających działalności organizacji na rynku. Ma on charakter ciągły i polega na stałym zbieraniu, przetwarzaniu i monitorowaniu informacji (wiedzy), dzięki czemu możliwe jest kreowanie nowych aktywów intelektualnych, które pozwalają na tworzenie nowych rozwiązań i wytworów klasyfikowanych jako własność intelektualna lub przemysłowa.

Własność intelektualna to, jak już nadmieniano, rozmaite rezultaty twórczej działalności człowieka i organizacji. Określa się je również mianem „dóbr niematerialnych" i grupuje zasadniczo w dwa zbiory: własność przemysłową oraz autorską. Własność intelektualna ma charakter dynamiczny, dlatego też jej zakresem obejmowane są coraz to nowe dobra. Własność przemysłową chronią przepisy zwane „prawem własności przemysłowej”, podczas gdy własności autorskiej dotyczą przepisy „,prawa autorskiego”. Własność intelektualna dotyczy także takich dóbr, których ochrona prawna wykracza poza przepisy prawa własności przemy- 
słowej oraz prawa autorskiego. Wynika ona z wielu szczegółowych i zróżnicowanych ustaw oraz regulacji. Chodzi tutaj o prawne zabezpieczenie takiej własności intelektualnej, jak: bazy danych, know-how, wiedza tradycyjna, zasoby genowe, formaty programów telewizyjnych i radiowych czy domeny internetowe. Mark Blaxill i Ralph Eckardt (2009, s. 10-11) wyróżniają własność intelektualną w ujęciu technicznym, prawnym (Dereń 2014) i biznesowym. Ujęcie biznesowe jest interesujące $\mathrm{z}$ tego punktu widzenia, że akcentuje znaczenie ekonomiczne, strategiczne i rynkowe różnych kategorii określanych jako własność intelektualna.

W opinii autorów proponowaną przez Allen piramidę zasobów niematerialnych należy uzupełnić o kategorię potencjału intelektualnego jako swoistego fundamentu rozwoju przedsiębiorczości intelektualnej (Dereń, Skonieczny 2017, s. 63). Definiując potencjał intelektualny, należy jednak ustalić, czy potencjał to pojęcie identyczne $\mathrm{z}$ intelektem, czy też z inteligencją. Zatem co stanowi istotę pojęcia intelektu, jaki jest jego zakres i czy ,inteligencja” jest terminem tożsamym z intelektem? Te i wiele innych pytań nie znajduje wyczerpujących odpowiedzi w literaturze. Natomiast zdaniem wielu autorów ,intelekt” i ,inteligencja” są pojęciami tożsamymi.

Zgodnie z definicją Władysława Kopalińskiego intelekt to „umysł, rozum, inteligencja (w odróżnieniu od uczucia, woli, zmysłów), suma zdolności umysłowych, doświadczenia, wiedzy człowieka" (Kopaliński 2014). Według autora inteligencja jest pojęciem równoważnym z pojęciem intelektu. Z kolei w Słowniku psychologii pod redakcją Arthura i Emily Reberów można znaleźć odrębne i niezależne zdefiniowanie obu pojęć, to znaczy inteligencji, która została określona jako „zdolność do korzystania z doświadczenia” (Reber, Reber 2005, s. 288), jak również intelektu, zdefiniowanego w postaci terminu „odnoszącego się wyłącznie do funkcji ludzkiego umysłu związanej z racjonalnym myśleniem, obejmującego całość procesów poznawczych" (Reber, Reber 2005, s. 287).

Popularna encyklopedia powszechna podaje natomiast, że intelekt (łac. intellectus - 'zdolność pojmowania, rozum') „to zdolności umysłowe, wiedza i doświadczenie danej osoby" (Popularna encyklopedia powszechna 2006, s. 339). W Stowniku wyrazów obcych, redagowanym przez Elżbietę Sobol, „intelekt” ukazany jest w postaci „całokształtu wiedzy i zdolności umysłowych człowieka” (Sobol 2002). W Słowniku psychologii pod redakcją Jerzego Siuty inteligencja określona jest tymczasem jako „zdolność umysłowa do rozumienia, rozumowania, wnioskowania, [...] myślenia abstrakcyjnego, [...] rozwiązywania problemów, [...] zdolność uczenia się" (Siuta 2005, s. 111).

O tym, jak ważny jest potencjał intelektualny, kapitał intelektualny, aktywa intelektualne oraz własność intelektualna i przemysłowa jako elementy składowe przedsiębiorczości intelektualnej, świadczą działania podejmowane w przedsiębiorstwie Apple mające na celu ich ochronę. Staranna ochrona aktywów intelektualnych zarówno na zewnątrz, jak i wewnątrz organizacji rozciągała się też na łańcuch dostaw Apple'a. Podejmowane przez firmę środki ostrożności miały na celu 
ochronę tajemnic handlowych i własności intelektualnej oraz utrudnienie i ograniczanie konkurentom reagowania na takie działania ochronne. Ponadto działania te chroniły istniejące produkty Apple'a przed spadkiem sprzedaży, albowiem klienci byli mniej skłonni nabywać nowsze jej wersje, gdy nie wiedzieli, kiedy się pojawią one na rynku. Zatem dla Apple'a ochrona zasobów intelektualnych w pierwszej dekadzie XXI wieku stanowiła strategiczny instrument pozwalający na podniesienie sprzedaży produktów (Yoffie, Cusumano 2016, s. 172-173).

\section{Cechy własności intelektualnej}

Własność intelektualna nie jest pojęciem, które należy rozpatrywać wyłącznie w aspekcie prawnym. Współcześnie ma ona również wymiar zarządczy i w tym znaczeniu rozumiana jest jako zasób niematerialny przedsiębiorstwa. W praktyce oznacza to, że przedsiębiorstwo powinno odejść od jednowymiarowego (najczęściej prawnego) postrzegania własności intelektualnej na rzecz podejścia zasobowego. Według Krzysztofa Obłója (2014, s. 91) podstawową przesłanką teorii zasobowej jest założenie, że przedsiębiorstwo jest zbiorem cennych zasobów materialnych i niematerialnych, skumulowanej wiedzy i umiejętności. W procesie zarządzania tymi zasobami ochrona (zabezpieczanie) staje się istotną funkcją zarządzania całą organizacją, pozwalającą na uzyskiwanie realnych korzyści finansowych.

Na rysunku 2 przedstawiono zmodyfikowany model DNA innowatora, który wzbogacono o ochronę zasobów intelektualnych, rozumianą jako proces realizowany na poziomie twórczych rezultatów. W opinii autorów jest to umiejętność strategiczna dla rozwoju przedsiębiorstw, ponieważ dzięki niej organizacje mogą być partnerami w rywalizacji rynkowej. Znaczenie tej umiejętności coraz bardziej wzrasta we współczesnej gospodarce, w której zasoby intelektualne wymagają nie tylko nakładów finansowych, lecz także działań związanych z ich ochroną.

Odwaga do
wprowadzania
innowacji:
- kwestionowanie
status quo
- podejmowanie
ryzyka

Umiejętności
behawioralne:
- kwestionowanie
- obserwowanie
- nawiązywanie
kontaktów
- eksperymentowanie
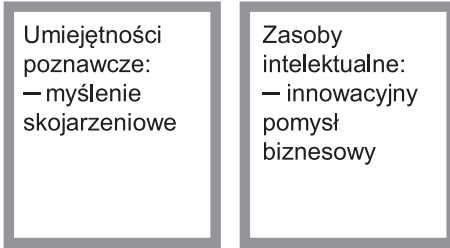

Zabezpieczanie zasobów intelektualnych

Rysunek 2. Ochrona zasobów intelektualnych jako składnik modelu DNA innowatora Źródło: opracowanie własne na podstawie Dyer, Gregersen, Christensen 2012, s. 23.

Proces ochrony własności intelektualnej jest zdeterminowany przez takie cechy zasobów własności intelektualnej, jak: niezawłaszczalność, niepoliczalność, 
niepodzielność, brak możliwości zużycia w trakcie wykorzystania, zdolność do komercjalizacji i użyteczność. Cechy te były analizowane i weryfikowane w badaniach ankietowych przeprowadzonych $\mathrm{w}$ grupie 138 przedsiębiorstw sektora MŚP i opublikowane w raporcie Stan wiedzy na temat zarzadzania i ochrony wtasności intelektualnej $w$ przedsiębiorstwach sektora MŚP $w$ regionie Dolnego Śląska (Dereń 2016).

Pierwsza z wymienionych cech to niezawłaszczalność. Idea czy nowe rozwiązanie będące rezultatem twórczej aktywności człowieka pozostają bowiem ukryte do czasu ich uzewnętrznienia. Tak więc twórca nie zawłaszcza swojej twórczości, jak czyni to na przykład właściciel gruntu, który zakazuje dostępu do niego. Twórca zapewnia sobie jednak prawo do kontroli sposobu korzystania ze swojego wytworu twórczego. W szczególności zainteresowany jest tym, aby uniemożliwić rozporządzanie nim w sposób niekontrolowany, na przykład sprzedaż czy czerpanie zeń zysków. Twórca nie może natomiast uczynić nic, by zapobiec naśladowaniu swojego pomysłu. Nabywając produkt — rezultat twórczej pracy — zdobywa się bowiem szczegółową, odtwórczą wiedzę o tym produkcie, o jego budowie i funkcjach. Prowadzi to do powstawania praktyki naśladownictwa ${ }^{1}$. W praktyce nowy pomysł, informacja czy rozwiązanie może stanowić początek procesu innowacyjnego, rodząc szereg kolejnych innowacji, które tym trudniej zawłaszczyć czy kontrolować.

Drugą cechą pozwalającą na akcentowanie odmienności własności idei, pomysłów, rozwiązań czy nowej wiedzy i informacji jest ich niepoliczalność. W zasadzie mamy bowiem do czynienia ze ,światem idei, pomysłów i informacji”, a ta niepoliczalność ukazuje możliwości twórcze ludzi i organizacji, które właściwie nie mają żadnych granic.

Trzecią cechą własności intelektualnej jest niepodzielność. Trudno podzielić tego typu dzieło, na przykład żeby zbyć jedynie część pomysłu albo tylko prawo do jego korzystania. Na tej cesze zasadza się zatem ekonomiczny problem opłacalności inwestycji w innowacje ${ }^{2}$. Kenneth Arrow (1951, s. 507-537) wykazał to poprzez stwierdzenie, że najbardziej racjonalny ekonomicznie byłby pełny dostęp do wiedzy i informacji dla wszystkich uczestników „gry rynkowej”. Jednocześnie taka dostępność wykluczałaby opłacalność inwestycji w innowacje jako przesłanki konkurowania.

${ }^{1}$ Badania wskazują, że tego rodzaju odtwórczość jest sytuacją dominującą i często prowadzi do tak zwanych innowacji udoskonalających (Christensen, McDonald, Raynor 2016). Innym nurtem jest formuła konkurencyjności pasożytniczej, wykorzystującej wypracowane wartości intelektualne bez ponoszenia kosztów (Michalska, Matczuk 2017).

2 W szerokim tego słowa rozumieniu ,innowacja” (od. łac. innovatio, czyli 'odnowienie') to ciąg działań prowadzących do wytworzenia nowych lub ulepszonych produktów, procesów technologicznych lub systemów organizacyjnych. Termin ten do ekonomii wprowadził Joseph A. Schumpeter, wskazując przy tym na pięć przypadków występowania innowacji: stworzenie nowego produktu; zastosowanie nowej technologii, metody produkcji; stworzenie nowego rynku, pozyskanie nieznanych dotąd surowców; reorganizacje określonych gałęzi gospodarki (Wiśniewska 2013, s. 10). 
Własność intelektualną charakteryzuje również brak możliwości jej zużycia w trakcie wykorzystania i doskonała płynność, co oznacza, że można ją przekształcić w dowolny zasób materialny (Koźmiński, Jemielniak 2008, s. 110), na przykład prawa autorskie można zamienić na źródło finansowania.

Wynika z tego, że innowacjom sprzyjają zarówno czynniki nieekonomiczne (ambicja, wartości, zaangażowanie przedsiębiorcy), jak i czynniki hamujące dyfuzję informacji: czas, zaawansowanie naukowo-technologiczne nowych pomysłów czy wrodzony konserwatyzm konsumentów i producentów. W przeszłości znaczenie miał dodatkowo dystans, na przykład geograficzny - dajmy na to: technologia wytwarzania szkła w weneckim Murano przez ponad sto lat była niedostępna dla innych. Być może zatem globalizacja jako taka nie sprzyja opłacalności innowacji, a w konsekwencji rodzi pytanie: co jest ważniejsze — zysk czy rozwój?

Piątą cechą własności intelektualnej jako zasobu jest jego zdolność do komercjalizacji. Jest to zdolność doprowadzenia własności intelektualnej do postaci rozwiązania gotowego do sprzedaży rynkowej i konkurowania ${ }^{3}$. Zdolność ta jest dynamiczna, zmienna i zależna od wielu czynników. Jest ukierunkowana na przekazywanie intelektualnej wiedzy, informacji i twórczych umiejętności do procesu produkcyjnego $\mathrm{w}$ celu ich udanego urynkowienia w postaci produktów.

W świetle tej piątej cechy - komercjalizacji — należy odnieść się do znanej z literatury konkluzji. Wykazano już bowiem, że prywatna własność dóbr materialnych prowadzi z reguły do konkurencji i wręcz jej sprzyja. Natomiast własność intelektualna prowadzi do powstawania trwałych monopoli, ograniczając konkurencję i współpracę. Ta ostatnia konkluzja prowadzi do konieczności identyfikowania źródeł (sposobów) pokonywania tych zagrożeń. Problem ten analizował w swoich rozważaniach Joseph Schumpeter (2009), który opowiadał się za tak zwaną twórczą destrukcją. Według tego stanowiska na danym etapie rozwoju technologicznego monopol intelektualny danego producenta pozwala mu dominować na rynku, choć trwa to krótko, gdyż dzięki konkurencji pojawiają się całkowicie nowe i lepsze pomysły, przekształcane w rozwiązania rodzące nowe produkty - w ten sposób wypierani są ustanowieni wcześniej monopoliści i ustanawiani nowi. Teoria ta $\mathrm{w}$ istocie zakłada, że monopol sprzyja innowacjom o tyle, o ile istnieje konkurencja między innowatorami. W praktyce tak zawiązane monopole są bardzo trwałe. Badania Jennifer Aaker (1997, s. 347-356) dowodzą, że w ciągu kilkudziesięciu lat trwałość postrzegania najpopularniejszych marek w zasadzie pozostaje niezmienna. Jak piszą obrońcy wolności intelektualnej Michele Boldrin i David Levine, „możemy jedynie zawdzięczać szczęściu lub ówczesnemu sądownictwu, że Apple i IBM nie mogły w latach 70. opatentować komputera osobistego i jego głównych komponentów" (Kaczmarczyk 2013, s. 68).

3 W piśmiennictwie pojęcie komercjalizacji określa się jako działanie, które sprawia, że coś, co ma potencjalną wartość i zdolność do przynoszenia zysku, zostaje sprzedane, wyprodukowane, udostępnione lub użytkowane w celu osiągnięcia zysku lub wykreowania kapitału (Dereń 2014, s. 120). 
Kolejna cecha własności intelektualnej jako zasobu to użyteczność. Mechanizm społeczny w obrocie własnością intelektualną jest bowiem inny niż w wypadku klasycznej własności materialnej. W tej ostatniej nie ma miejsca na „niewłaścicieli" po to, by właściciel miał swobodę sprawowania władztwa nad swoją rzeczą. Tymczasem własność intelektualna — w podejściu zasobowym tego wykluczenia nie wymaga. Jeśli ktoś jest użytkownikiem rozwiązań będących w domenie publicznej, w niczym nie zmniejsza to możliwości użytkowania ich również przez innych. Zachowuje się więc społeczną użyteczność tych zasobów. Mało tego, im więcej osób z nich korzysta, tym większa jest umownie korzyść ogólna. Jednocześnie jednak dobrem, które zmniejsza się, są dochody, jakie monopol może przynieść właścicielowi, gdy polega on na wyłączności praw do sprzedaży i udostępniania dóbr — jest to monopol rozporządzania dobrem. Należy jednak podkreślić, że zamykanie dostępu ogranicza możliwość opracowania nowych modeli biznesowych opartych na szerokim dostępie użytkowników do zasobów własności intelektualnej.

W dyskursie na temat własności intelektualnej zarówno ekonomiści, socjologowie, prawnicy, jak i specjaliści od zachowań organizacyjnych akcentują społeczną naturę własności intelektualnej. Takie określenie wyraźnie podkreśla kontekst zasobowy własności intelektualnej. Definiując stosunek jednostek i zbiorowości do szczególnego dobra - produktu pracy umysłowej - nawiązywany w zamiarze jego wykorzystania, akcentuje się jego walory użyteczności. Takie ujęcie cech własności intelektualnej nawiązuje do ogólnej definicji pojęcia ,instytucja własności” jako przesłanki większej. Jednocześnie postrzeganie własności intelektualnej jako zasobów o określonych cechach (atrybutach) pozwala na ukazanie ich specyfiki, często tak trudnej do zrozumienia z punktu widzenia tradycji, wspieranej ustalonymi zasadami i normami, a także traktowania zasobów materialnych jako fundamentalnej podstawy gospodarowania (Stankiewicz 2012, s. 78-79). Katalog cech zasobowych własności intelektualnej należy uzupełnić o zdolność (umiejętność) do ochrony (Dereń 2015, s. 65-79).

Omawiana ochrona własności intelektualnej jest procesem zabezpieczania wiedzy i informacji nie tylko na etapie ich generowania, lecz także w procesie dzielenia się nimi w toku działalności gospodarczej. Ramy prawne procesów rynkowych i przyjęta praktyka gospodarcza wykształciły instrumenty (strategie) pozwalające na utrzymywanie tej ochrony na rynku. Wymiana zasobów intelektualnych może odbywać się poprzez: licencje, rozpoczęcie własnej działalności gospodarczej, sprzedaż i działalność typu joint venture. Mimo odmienności wskazane instrumenty łączy wspólna podstawa - udzielanie prawa do korzystania z wiedzy i informacji powstałej w danej organizacji.

Określone przez państwo aspekty prawne rynkowych procesów wymiany dóbr i usług dla obszaru własności intelektualnej ustanawiają porządek prawny określany jako „prawo własności intelektualnej”. Jest to zbiór legislacyjnych form własności intelektualnej wraz z ich szczególnymi formami jurysdykcyjny- 
mi, ukształtowanymi przez orzecznictwo i rozwój prawa. Istotnymi elementami tych regulacji prawnych są: prawo patentowe, prawo do wzorów przemysłowych, prawo do wzorów użytkowych, prawo o znakach towarowych oraz prawo autorskie. Wspierając się podstawą konstytucyjną, tworzą one określoną całość, która stanowi zasadniczą gwarancję własności prywatnej, będącej ogólną i nadrzędną podstawą ochrony prywatnych form własności — koncepcję własności intelektualnej. Do tego dochodzą regulacje prawne dotyczące konkurencji o węższym zakresie, jak na przykład ustawa o zwalczaniu nieuczciwej konkurencji lub prawo antymonopolowe. Tworzone przez nie ramy prawne i mechanizmy sprawowania kontroli nakierowane są również na negatywne dla konkurencji skutki oddziaływania form użytkowania własności intelektualnej.

\section{Wnioski}

Zarządzanie zasobami własności intelektualnej jest procesem, w którym organizacja generuje wartość i dzieli się z nią z innymi uczestnikami rynku, z którymi współpracuje. Integralną częścią tego procesu jest ochrona własności intelektualnej. Ochronę tę charakteryzuje duża doza niepewności i ryzyko. Już na etapie angażowania zasobu intelektualnego w celu stworzenia konkretnej formy, na przykład wynalazku, rezultaty są trudne do przewidzenia. $\mathrm{Z}$ reguły nie wiadomo, czy wynalazek ten i prawa patentowe do niego zainteresują potencjalnych nabywców, licencjobiorców i innych korzystających z zasobu intelektualnego. Ponadto odbiór, identyfikacja i wycena praw własności jako zagregowanego zasobu wiedzy i informacji nie jest łatwym procesem. Wycena obejmuje wiele czynności wykonywanych przez zespół ekspertów, w tym rzecznika patentowego, radcę prawnego, biegłego rewidenta, a także analityka finansowego. Wynikiem ich pracy jest ekspertyza, która może stać się podstawą do dalszych działań, w tym optymalizacji podatkowej przedsiębiorstwa czy ustalenia wysokości opłat licencyjnych za korzystanie z marki.

Ochrona prawna idei, pomysłów i rozwiązań, traktowanych jako osiągnięcia człowieka w sferze wartości niematerialnych, jest pochodną nakładu pracy i środków, a także kreatywności i talentu. Połączenie potencjału intelektualnego z potencjałem produkcyjnym organizacji decyduje o jej sile na rynku. Oczywiście utrzymanie zasobów materialnych i intelektualnych oraz potrzeba ich ciągłego rozwoju są kosztowne. Dlatego też uzasadnieniem ponoszenia wysokich nakładów jest oczekiwanie na wygenerowanie dzięki tym składnikom wyższej wydajności produkcji, wzrostu sprzedaży, a w konsekwencji zwiększenie dochodów. 


\section{Bibliografia}

Aaker J. (1997), Dimensions of brand personality, „Journal of Marketing Reasearch” 34, nr 3, s. $347-356$.

Allen K. (2010), Entrepreneurship for Scientists and Engineers, Upper Saddle River.

Arrow K.J. (1951), An extension of the basic theorems of classical welfare economics, [w:] Proceedings of the second Berkley Symposium on Mathematical Statistics and Probability, red. J. Neyman, Berkley, s. 507-532.

Bainbridge D. (2009), Intellectual Property, Harlow.

Barrett M. (2008), Intellectual Property, New York.

Bielig A. (2014), Rola własności intelektualnej w gospodarce. Teoria i praktyka, Warszawa.

Blair R.D., Cotter T.F. (2005), Intellectual Property: Economic and Legal Dimensions of Rights and Remedies, New York.

Blaxill M., Eckardt R. (2009), The Invisible Edge. Taking Your Strategy to the Next Level Using Intellectual Property, Johanneshov.

Boldrin M., Levine D. (2008), Against Intellectual Monopoly, New York.

Christensen C.M., McDonald P., Raynor M.E. (2016), Czym jest przełomowa innowacja, „Harvard Business Review. Polska" nr 159, https://www.hbrp.pl/a/czym-jest-przelomowa-innowacja/ 1HRaiLxz5 (dostęp: 1.10.2018).

Commons J.R. (1931), Institutional economics, „American Economic Reviev” 21, s. 648-657.

Dereń A.M. (2014), Zarzadzanie własnościa intelektualna w transferze technologii, Warszawa.

Dereń A.M. (2015), Wykorzystanie instytucjonalnych form ochrony własności intelektualnej w przedsiębiorstwie - zarys problematyki, [w:] Zarzadzanie nowoczesna organizacja: wybrane zagadnienia, red. M. Dąbrowska, R. Gnitecka, Legnica, s. 40-53.

Dereń A.M. (2016), Stan wiedzy na temat zarzadzania i ochrony własności intelektualnej $w$ przedsiębiorstwach sektora MŚP w regionie Dolnego Śląsk, raport PRE, Wrocław.

Dereń A.M., Skonieczny J. (2017), Cykl rozwoju przedsiębiorczości intelektualnej organizacji zarys problemu, [w:] Innowacyjność w gospodarce, organizacji i technice, red. A. Balcerak, Z. Malara, Warszawa, s. 62-71.

Dyer J., Gregersen H., Christensen C.M. (2012), DNA innowatora. Zostań mistrzem we wdrażaniu innowacji, Warszawa.

Kaczmarczyk M. (2013), Czy własność intelektualna jest własnościa, [w:] Prawa autorskie w czasach zmiany. O normach społecznych korzystania z treści, red. M. Danielewicz, A. Tarkowski, Warszawa, s. 65-72.

Kasiewicz S., Rogowski W., Kicińska M. (2006), Kapitat intelektualny. Spojrzenie z perspektywy interesariuszy, Kraków.

Kopaliński W. (2014), Słownik wyrazów obcych i zwrotów obcojęzycznych z almanachem, Warszawa. Koźmiński A.K., Jemielniak D. (2008), Zarzadzanie od podstaw, Warszawa.

Krupp S., Schoemaker P.J.H. (2016), Zwycięskie strategie. Jak liderzy tworza przyszłe sukcesy, Warszawa.

May Ch. (2007), The World Intellectual Property Organization: Resurgence and the Development, New York.

Michalska M., Matczuk J. (2017), W jaki sposób można skutecznie obronić autorski pomyst, „Rzeczpospolita" 3.03., s. D4.

Obłój K. (2014), Strategia organizacji, Warszawa.

Popularna encyklopedia powszechna (2003), t. 12, Kraków.

Reber E., Reber A.S. (2015), Słownik psychologii, red. I. Kurcz, K. Skarżyńska, Warszawa.

Schumpeter J. (2009), Kapitalizm, socjalizm, demokracja, przeł. M. Rusiński, Warszawa.

Sherman A.J. (2012), Harvesting Intangible Assets. Uncover Hidden Revenue in Your Company's Intellectual Property, New York. 
Sikorski C. (2001), Zachowania ludzi w organizacji, Warszawa.

Siuta J. (2005), Słownik psychologii, Kraków.

Sobol E. (2002), Stownik wyrazów obcych, Warszawa.

Stankiewicz W. (2012), Zarys wyktadu, Warszawa.

Wiśniewska S. (2013), Skuteczność niekomercyjnych instytucji otoczenia biznesu we wspieraniu innowacji marketingowych matych i średnich przedsiębiorstw, Kraków.

Ujwary-Gil A. (2010), Kapitat intelektualny — problem interpretacji kluczowych terminów, „Organizacja i Kierowanie" nr 2 (140), s. 87-104.

Yoffie D.B., Cusumano M.A. (2016), Zasady strategii. Bill Gates, Andy Grove i Steve Jobs. Pięć ponadczasowych lekcji, Warszawa. 